\title{
Isolated posterior mitral leaflet prolapse: Resect, respect, or resect with respect?
}

\author{
Manuel J. Antunes, MD, PhD, DSc
}

\footnotetext{
From the Center of Cardiothoracic Surgery, University Hospital and Faculty of Medicine, University of Coimbra, Coimbra, Portugal.

Disclosures: Author has nothing to disclose with regard to commercial support.

Received for publication Aug 4, 2017; accepted for publication Aug 28, 2017; available ahead of print Sept 21, 2017.

Address for reprints: Manuel J. Antunes, MD, PhD, DSc, Centro de Cirurgia Cardiotorácica, Centro Hospitalar Universitário de Coimbra, Praceta Professor Mota-Pinto, 3000-075 Coimbra, Portugal (E-mail: antunes.cct. chuc@sapo.pt).

J Thorac Cardiovasc Surg 2018;155:129-30

$0022-5223 / \$ 36.00$

Copyright (C) 2017 by The American Association for Thoracic Surgery

http://dx.doi.org/10.1016/j.jtcvs.2017.08.093
}

Prolapse of the mitral valve leaflets from fibroelastic deficiency is a common cause of mitral regurgitation (MR). Isolated posterior leaflet prolapse, usually limited to the central scallop of the leaflet (P2), is the most prevalent form of prolapse.

Repair is now widely accepted as the preferential method of treatment of MR, and the classic technique used for correction of posterior leaflet prolapse is based on partial or complete resection of $\mathrm{P} 2$ and reconstitution of the leaflet continuity by direct suture, as popularized by Carpentier $^{1}$ in his seminal honorary guest lecture to The American Association for Thoracic Surgery annual meeting in 1983 as part of the now famous "French correction." This is technically a rather simple procedure that should be within the reach of every cardiac surgeon interested in mitral valve preservation. In experienced hands, it may be used in almost all patients and results in excellent long-term durability. ${ }^{2}$

Despite these excellent results, it has been recognized that this technique causes loss of mobility of the posterior leaflet. Although this loss of mobility does not appear to be significantly deleterious with regard to global valve function, alternatives have nonetheless been explored, and the most well known is that popularized by Perier and colleagues ${ }^{3}$ as the "respect rather than resect" concept. It is based on complete preservation of the leaflet and correction of the prolapse by supporting the diseased leaflet segment with artificial chordae constructed from polytetrafluorethylene suture material, usually one pair to each papillary muscle.

Artificial chordae have now been used in the treatment of prolapsed mitral leaflets, whether caused by rupture or by elongation of chordae, for nearly 3 decades, with excellent long-term durability. ${ }^{4}$ Implantation of artificial chordae is technically more demanding, however, especially with regard to the correct length adjustment, for which many techniques have been described. Polytetrafluorethylene is a rather slippery material, with knotting requiring some experience. The material is known to be very flexible and

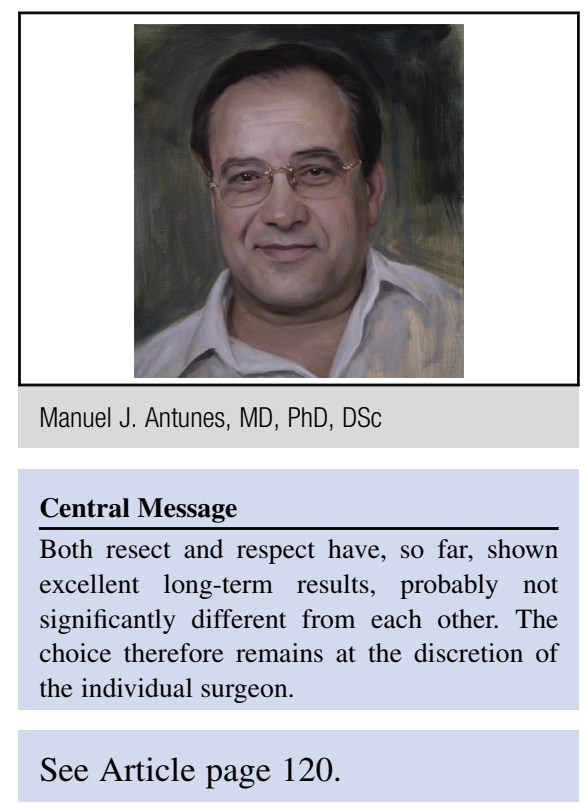

resistant, more so than any other suture material, although cases of midterm to long-term polytetrafluorethylene rupture have been described.

We are thus in the presence of 2 very efficient alternative techniques that, however, have never been appropriately compared. It is in this milieu that Mazine and colleagues ${ }^{6}$ from Toronto have performed a review and meta-analysis of chordal replacement versus leaflet resection for posterior leaflet prolapse, published in this edition of our Journal. In this study, Mazine and colleagues ${ }^{6}$ found that "leaflet resection and chordal replacement are associated with similar survival and freedom from recurrent MR. However, chordal replacement may be associated with greater freedom from reoperation and improved post-operative left ventricular function."

In the absence of randomized trials, studies like this are of importance to help surgeons determine their own approach, and Mazine and colleagues ${ }^{6}$ are to be congratulated for this excellent work. But such a study has natural shortcomings that may affect the conclusions. The great variability of the outcomes reported by the different papers analyzed may result from the details of the techniques used, which may not have always been reported, beyond the simple equation "resect versus respect." For example, the resection technique has had several modifications since the initially described quadrangular resection (depicted in the article's central picture) to the now more frequently 
used triangular resection, and the extent of leaflet resection is also widely variable, with an evolving consensus of the less, the better. Interestingly, there were no significant differences in operative times (crossclamping, cardiopulmonary bypass) between the approaches, but there may have been some aspects that influenced the left ventricular function and even the recurrence of MR.

In addition, an annuloplasty is usually performed to consolidate the repair, and the great variability of devices and sizes used have transformed the different series into rather heterogeneous population groups, extremely difficult to compare. Also, because the different cohorts were not entirely contemporaneous (the use of the neochordae is more recent and has increased with time), there is a potential learning curve effect. Hence, as stated by Mazine and colleagues, "this systematic review highlighted the lack of high-quality data to inform decision making regarding the ideal surgical technique for mitral reconstruction." Although they tried to compensate for this between-trial heterogeneity by using sophisticated statistical methods, the end results may still be somewhat skewed.

I must confess, however, that I was not surprised by the conclusions derived from this work. Actually, Mihos and associates $^{7}$ have just published a similar study (meta-analysis) with similar conclusions. Mihos and associates ${ }^{7}$ found that "at 2.9-year follow-up, chordal replacement for isolated posterior mitral valve prolapse was associated with a lower reoperation rate and favorable valve hemodynamics, when compared with leaflet resection." In addition, isolated chordal reconstruction with leaflet preservation permits the use of larger annuloplasty rings and thus is associated with lower transmitral gradients, as has also been confirmed by Chua and colleagues. ${ }^{8}$

In conclusion, I fully support the conclusions of Mazine and colleagues" that "high-quality RCTs of chordal replacement versus leaflet resection are needed." At least to me, however, the main conclusion to be derived is that both techniques have so far shown excellent long-term results, probably not significantly different. The choice between the approaches therefore remains largely at the discretion of the individual surgeon or team. I, like many others, have progressively been converting myself to a "respect rather than resect" surgeon. We all have often come across cases, however, in which a very redundant degenerative $\mathrm{P} 2$ segment recommends the use of a hybrid approach of partial leaflet resection accompanied by chordal support of the remaining P2 tissue after reapproximation.

This we could call "resect with respect."

\section{References}

1. Carpentier A. Cardiac valve surgery-the "French correction." J Thorac Cardiovasc Surg. 1983;86:323-37.

2. Correia PM, Coutinho GF, Branco C, Garcia A, Antunes MJ. Surgical treatment of posterior mitral valve prolapse: towards 100\% repair. J Heart Valve Dis. 2015;24: 752-9.

3. Perier P, Hohenberger W, Lakew F, Batz G, Urbanski P, Zacher M, et al. Toward a new paradigm for the reconstruction of posterior leaflet prolapse: midterm results of the "respect rather than resect" approach. Ann Thorac Surg. 2008;86:718-25; discussion 718-5.

4. Salvador L, Mirone S, Bianchini R, Regesta T, Patelli F, Minniti G, et al. A 20-year experience with mitral valve repair with artificial chordae in 608 patients. J Thorac Cardiovasc Surg. 2008;135:1280-7.

5. Antunes MJ, Coutinho GF. Rupture of expanded polytetrafluoroethylene neochordae used for mitral valve repair: does size matter? J Thorac Cardiovasc Surg. 2014;148:2442-3.

6. Mazine A, Friedrich JO, Nedadur R, Verma S, Ouzounian M, Jüni P, et al. Systematic review and meta-analysis of chordal replacement versus leaflet resection for posterior mitral leaflet prolapse. J Thorac Cardiovasc Surg. 2018; 155:120-8.e10

7. Mihos CG, Yucel E, Santana O. A systematic review and meta-analysis of chordal replacement versus leaflet resection for isolated posterior mitral valve prolapse. J Cardiovasc Surg (Torino). 2017;58:779-86.

8. Chua YL, Pang PY, Yap YP, Abdul Salam ZH, Chen YT. Chordal reconstruction versus leaflet resection for repair of degenerative posterior mitral leaflet prolapse. Ann Thorac Cardiovasc Surg. 2016;22:90-7. 